\title{
Molecular cloning and mapping of casein kinase 2 alpha and beta subunit genes in barley
}

\author{
K. Kato, S. Kidou, and H. Miura
}

\begin{abstract}
Casein kinase 2 (CK2) is a ubiquitous, highly pleiotropic, constitutively active, and messenger-independent Ser/Thr protein kinase. It is found in two different forms: the heterotetrameric CK2, composed of two alpha catalytic subunits and two beta regulatory subunits, and the monomeric CK2 alpha, consisting of the alpha catalytic subunit. In the present study, we isolated barley cDNA clones of the CK2 alpha and beta subunit genes, designated $H v C K 2 A$ and $H v C K 2 B$, respectively. Chromosome assignment, using a set of wheat-barley disomic chromosome addition lines, and RFLP mapping, using two doubled haploid populations, showed that $H \nu C K 2 A$ was duplicated on the short arm of chromosome $2 \mathrm{H}$ and the long arm of chromosome $5 \mathrm{H}$ (designated $H v C K 2 a-2 H$ and $H v C K 2 a-5 H$, respectively), and a single copy of $H_{v} C K 2 B$ was located on the long arm of chromosome $1 \mathrm{H}$ (designated $H v C K 2 b$ ). A PCR-Southern hybridization experiment demonstrated that the $H v C K 2 A$ sequence originated from the $H v C K 2 a-5 H$ locus, showing that at least $H v C K 2 a-5 H$ was expressed. The present cDNA sequences and genomic organization of the two subunits will facilitate further functional analysis of CK2 in barley.
\end{abstract}

Key words: barley, casein kinase 2, cDNA cloning, RFLP mapping.

Résumé : La caséine kinase 2 (CK2) est une protéine kinase Ser/Thr ubiquiste, très pléiotropique, constitutive et qui ne dépend pas d'un messager. Elle est retrouvée sous deux formes différentes : (1) un hétérotétramère CK2 formé de deux sous-unités catalytiques alpha et de deux sous-unités régulatrices bêta, et (2) un monomère CK2 alpha formé uniquement de la sous-unité catalytique alpha. Dans le présent travail, les auteurs ont isolé des clones d'ADNc correspondant aux gènes codant pour les sous-unités CK2A et CK2B chez l'orge, lesquels gènes ont été nommés $H \nu C K 2 A$ et $H \nu C K 2 B$ respectivement. La cartographie chromosomique, à l'aide de lignées d'addition disomiques blé-orge, et la cartographie RFLP, chez deux populations de lignées haplö̈des doublées, ont montré que $H v C K 2 A$ est présent en deux exemplaires situés sur le bras court du chromosome $2 \mathrm{H}$ et sur le bras long du chromosome $5 \mathrm{H}$. Ces deux gènes ont été désignés respectivement $H v C K 2 a-2 H$ et $H v C K 2 a-5 H$. L'unique copie du gène $H v C K 2 B$ a été assignée au chromosome $1 H$ et a été désignée $H v C K 2 b$. Une hybridation Southern-PCR a révélé que la séquence $H v C K 2 A$ provenait à l'origine du locus $H v C K 2 a-5 H$ et que ce locus est exprimé. Ces séquences d'ADNc et l'organisation génomique des deux sous-unités faciliteront une plus ample analyse fonctionnelle des CK2 chez l'orge.

Mots-clés : orge, caséine kinase 2, clonage d'ADNc, cartographie RFLP.

[Traduit par la Rédaction]

\section{Introduction}

Protein kinase CK2 (casein kinase 2; EC 2.7.11.1) is a serine/threonine phosphotransferase that occurs ubiquitously in enkaryotes. CK2 is composed of two subunits, the alpha catalytic and beta regulatory subunits, which form the tetrameric structure $\alpha_{2} \beta_{2}$. However, both subunits can associate independently with other proteins, probably to regulate their functions in the cell (Boldyreff and Issinger 1997; Chen et al. 1997; Hériché et al. 1997; Willert et al. 1997). In addi-

Received 29 August 2007. Accepted 3 December 2007.

Published on the NRC Research Press Web site at

genome.nrc.ca on 20 February 2008.

Corresponding Editor: G. Scoles.

K. Kato ${ }^{1}$ and H. Miura. Department of Crop Science, Obihiro University of Agriculture and Veterinary Medicine, Inada 2-11, Obihiro, Hokkaido, 080-8555, Japan.

S. Kidou. Cryobiosystem Research Center, Faculty of

Agriculture, Iwate University, Ueda 3-chome, Morioka, Iwate,

020-8550, Japan.

'Corresponding author (e-mail: kiyoaki@obihiro.ac.jp). tion, the alpha subunit has been isolated as a monomer with full activity from different species, especially plants (Dobrowolska et al. 1992; Ospina et al. 1992; Klimczak and Cashmore 1994; Espunya and Martìnez 1997).

CK2 has been widely studied in several organisms, demonstrating that it is involved in different processes such as cell proliferation (Seldin and Leder 1995), cell cycle progression (Hanna et al. 1995; Espunya et al. 1999; Barz et al. 2003), signal transduction (Chen et al. 1997), and transcriptional control (Lüscher et al. 1989). The majority of the CK2 substrates - more than 300 proteins identified to date - are nuclear proteins involved in DNA/RNAassociated functions, or cellular proteins involved in signal transduction (Meggio and Pinna 2003). In particular, CK2 has been shown to phosphorylate clock proteins in Drosophila (Lin et al. 2002; Akten et al, 2003), Neurospora (Yang et al. 2002), and Arabidopsis (Sugano et al. 1998, 1999; Daniel et al. 2004; Portolés and Más 2007), suggesting that it is an evolutionarily conserved component of molecular clocks across several kingdoms. In Arabidopsis, overexpression of CKB3 and CKB4 shortened the phase of circadian clock controlled genes and reduced the days to 
flowering under short and long days (CKB3) and short days (CKB4) (Sugano et al. 1999; Portolés and Más 2007). In rice (Oryza sativa L.), the heading date QTL Hd6 encodes the alpha subunit of CK2 (Takahashi et al. 2001). The variant allele of Hd6 in the japonica rice cultivar Nipponbare has a premature stop codon and encodes a truncated protein, while the corresponding functional allele in the indica rice cultivar Kasalath increases the days to heading under long-day conditions (Yamamoto et al. 2000; Takahashi et al. 2001).

The genetic control of variation in flowering time has been extensively studied in the tribe Triticeae (Poaceae). Major loci affecting photoperiod response have been mapped in barley (Hordeum vulgare L.). The Ppd-HI locus on chromosome $2 \mathrm{HS}$ controls flowering under long days but has no effect under short days, while $\mathrm{Ppd}-\mathrm{H} 2$ on $1 \mathrm{HL}$ controls flowering only under short days (Laurie et al. 1995). In addition, many QTLs controlling photoperiod response have been reported in barley. The $P p d-H I$ locus encodes a member of the CCT-domain pseudo-response regulator family, a class of genes involved in circadian clock functions (Turner et al. 2005). In addition, Szúcs et al. (2006) reported that the positional candidate for the photoperiod response effect at the $\mathrm{V} r n-H I$ locus was a member of the photoreceptor gene family, Phytochrome $C$. To clone the positional candidate genes relative to the remaining photoperiod response QTLS, investigation of additional gene family classes is needed. In hexaploid wheat (Triticum aestivum L.), a single cDNA clone of the CK2 alpha subunit was isolated, and its duplication in each wheat genome was estimated by Southern blotting. A single copy was assigned to the homoeologous group 5 chromosomes, and closely linked to $V r n-A l$ on the long arm of wheat chromosome $5 \mathrm{~A}$ (Kato et al. 2002). However, the second CK2 alpha subunit locus in wheat remains unmapped (Kato et al. 2002). In perennial ryegrass (Lolium perenne L.), two CK2 alpha subunit genes were mapped and one of the duplicated loci was coincident with the phenotypic variation of heading date (Shinozuka et al. 2005).

We investigated the possible role(s) of CK2 in the barley photoperiod response. The objectives of this study were to determine the nucleotide sequence of the cDNA clones encoding the CK2 alpha and beta subunits, and the genetic map positions of both of the subunit genes in barley. Based on the present data, we discuss whether barley CK2 subunit genes are positional candidates for photoperiod response QTLs.

\section{Materials and methods}

\section{Construction and screening of the cDNA library}

A cDNA library was constructed from mRNA prepared from 5-day-old barley (H. vulgare 'Minorimugi') seedlings

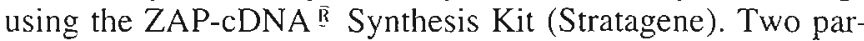
tial rice cDNA fragments encoding the CK2 alpha subunit (CK2A) (RefSeq accession no. NP_001058752) and the CK2 beta subunit (CK2B) (RefSeq acc. no. NP_001065415) were used as templates to generate each probe. Approximately $5 \times 10^{4}$ recombinants were screened by plaque hybridization and the hybridizing plaques were isolated. After 3 cycles of plaque purification, in vivo excisions of the pBluescript $\mathrm{SK}^{-}$vector were performed in the Escherichia coli $\mathrm{K}-12$ strain XL1-Blue. The nucleotide sequences of the isolated cDNA clones were determined using the Thermo Sequenase Cycle Sequencing Kit (Amersham Pharmacia Biotech, UK) with M13 universal and reverse primers.

\section{Plant materials for mapping}

For the chromosome assignments of the barley CK2A and CK2B genes, we used T. aestivum 'Chinese Spring', $H$. vulgare subsp. vulgare 'Betzes', and a set of 'Chinese Spring''Betzes' disomic chromosome addition lines possessing each of 'Betzes' chromosomes 2H to 7H (Islam et al. 1981).

For the genetic mapping study, we screened 4 parental combinations: Steptoe and Morex, Harrington and TR-306, Igri and Franka, and Oregon Wolf Barley 95 (OWB-95) and OWB-96. Based on the parental RFLP data, 2 populations were chosen for the present mapping study. The first population was Steptoe/Morex doubled haploid lines developed by the North American Barley Genome Mapping Project (Kleinhofs et al. 1993). The second population was the OWB doubled haploid lines (Costa et al. 2001). In the present RFLP mapping, we used 60 lines of the Steptoe/ Morex population and 67 lines of the OWB population.

\section{RFLP assays}

DNA was extracted from young leaves of each line using a modified CTAB method (Murray and Thompson 1980). Southern hybridization was conducted using the Gene Images labeling and detection system (Amersham Pharmacia Biotech, UK).

For the chromosome and chromosome arm assignments, RFLP assays were conducted by genomic Southern hybridization using barley CK2A and CK2B cDNAs as probe. Genomic DNA of 'Chinese Spring' and 'Betzes' and a set of wheat-barley disomic chromosome (arm) addition lines (Islam et al. 1981) was digested with ApaI, BamHI, BglII, HindIII, EcoRI, EcoRV, DraI, KpnI, and XbaI.

For genetic mapping, polymorphisms between two combinations of the parents were detected by genomic Southern hybridization. Genomic DNA of Steptoe, Morex, OWB-95, and OWB-96 was digested with ApaI, BamHI, BgllI, Dral, EcoRI, EcoRV, HindIII, KpnI, PstI, XbaI, XhoI, AluI, DdeI, HaeIII, Sall, and Scal. Genotypes for each line of the mapping populations were scored.

\section{Linkage analysis}

To locate barley $\mathrm{CK} 2 \mathrm{~A}$ and $\mathrm{CK} 2 \mathrm{~B}$ genes on the known genetic maps, the genotype data sets of each polymorphism were added to the previous genotype data sets (Kleinhofs et al. 1993; Costa et al. 2001). Linkage analysis was conducted using the "near" and "try" commands of MAPMAKER/ EXP 3 (Lander et al. 1987). The recombination frequencies were converted to centimorgans (cM) using the Kosambi mapping function (Kosambi 1944).

\section{PCR-Southern blotting}

To determine the original locus of the barley CK2A sequence, the following set of primers was developed for amplification of the whole putative exon sequence: Hvck2a-F (5'-ATGGCCGCATGAGCGATGC-3') and Hvck2a-R (5'TCATTGCGGTCGTGCCCTG-3'). Each $15 \mu \mathrm{L}$ amplification reaction contained $0.75 \mathrm{U}$ of TaKaRa Ex Taq polymer- 
ase (TaKaRa) and $50 \mathrm{ng}$ of template DNA. Amplification was performed under the following conditions: $94{ }^{\circ} \mathrm{C}$ for I min followed by 40 cycles of $94{ }^{\circ} \mathrm{C}$ for $1 \mathrm{~min}, 66^{\circ} \mathrm{C}$ for $1 \mathrm{~min} 30 \mathrm{~s}$, and $72{ }^{\circ} \mathrm{C}$ for $8 \mathrm{~min}$ with a final extension of $72{ }^{\circ} \mathrm{C}$ for $8 \mathrm{~min}$. Amplification products were separated on $1.0 \%$ agarose gel for $0.5 \mathrm{~h}$ at $100 \mathrm{~V}$ and visualized with ethidium bromide.

Southern analysis was performed to confirm that the PCR products were homologous to the CK2A sequence. The products were separated on $1.0 \%$ agarose gel and transferred to a nylon membrane (Hybond-N+), hybridized with the barley cDNA of the CK2A gene, and detected using the Gene Images labeling and detection system (Amersham Pharmacia Biotech, UK).

\section{Results}

\section{cDNA cloning of the CK2A and CK2B genes}

Plaque hybridization of the barley cDNA library identified two positive cDNA clones encoding CK2A and two positive cDNA clones encoding $\mathrm{CK} 2 \mathrm{~B}$. The inserts of the CDNA clones were subcloned into the pBluescript $\mathrm{SK}^{-}$vector by in vivo excisions and sequenced. Figure $1 \mathrm{~A}$ shows the entire nucleotide and deduced amino acid sequences of the longest cDNA clone encoding CK2A. The protein encoded by the ORF consists of 382 amino acids and exhibits high sequence similarity to other plant CK2As (data not shown). In addition, characteristic domains such as the ATP binding site, basic stretch (NLS), catalytic loop, and activation segment are completely conserved. Figure $1 \mathrm{~B}$ shows the entire nucleotide and deduced amino acid sequences of the longest cDNA clone encoding CK2B. The protein encoded by the ORF consists of 259 amino acids and exhibits $73 \%$ sequence similarity with $A$. thaliana CK2B (data not shown). Characteristic domains such as the N-terminal extension region, KEN box, D-box, acidic stretch, zinc finger domain, and positive regulatory region are completely conserved. We therefore concluded that these cDNA clones encode barley CK2A (gene $H \nu C K 2 A$, GenBank acc. no. AB252049) and CK2B (gene $H v C K 2 B$, GenBank acc. no. AB252050).

\section{Molecular mapping of $\mathrm{H} v \mathrm{CK} 2 \mathrm{~A}$}

\section{Chromosome assignments}

For each of the 9 restriction enzymes, the Southern hybridization study identified 1 to 4 restriction fragments that hybridized with $H v C K 2 A$ in 'Betzes'. Of these, the $10.0 \mathrm{~kb}$ BamHI, $2.0 \mathrm{~kb} B g l \mathrm{II}, 2.1 \mathrm{~kb} H$ HindIII, $3.5 \mathrm{~kb}$ and $7.5 \mathrm{~kb}$ EcoRI, $6.6 \mathrm{~kb}$ EcoRV, $3.0 \mathrm{~kb}$ DraI, $9.5 \mathrm{~kb} \mathrm{KpnI}$, and $2.5 \mathrm{~kb}$ $\mathrm{Xbal}$ fragments were assigned to the barley $2 \mathrm{H}$ chromosome (Fig. 2A). The $4.5 \mathrm{~kb}$ BamHI, $3.5 \mathrm{~kb}$ Bglli, $5.5 \mathrm{~kb}$ Dral, $6.6 \mathrm{~kb} \mathrm{KpnI}$, and $7.5 \mathrm{~kb} \mathrm{XbaI} \mathrm{fragments} \mathrm{were} \mathrm{assigned} \mathrm{to}$ the barley $5 \mathrm{H}$ chromosome (Fig. $2 \mathrm{~A}$ ). We concluded that the barley genome has duplicate copies of the $H v C K 2 A$ gene located on chromosomes $2 \mathrm{H}$ and $5 \mathrm{H}$.

\section{Genetic mapping on chromosome $2 H$}

Among all the fragments obtained from 10 restriction enzymes, the $9.5 \mathrm{~kb}$ Dral fragment on the $2 \mathrm{H}$ chromosome of 'Betzes' was detected in OWB-96 but not in OWB-95. The $18.5 \mathrm{~kb}$ DraI fragment was specific to OWB-95. We used these two fragments for further genetic mapping. Genotype data of the doubled haploid lines show that the OWB-96specific $9.5 \mathrm{~kb}$ DraI fragment and the OWB-95-specific $18.5 \mathrm{~kb}$ DraI fragment co-segregate and contribute to a single locus. Using the "near" command of MAPMAKER with the threshold of the likelihood value at 3.0, we found that 5 markers (X2.1, Pox, MWG949B, Hot1, Ebmac0684) on the short arm of chromosome $2 \mathrm{H}$ and 3 markers (ABG356, X2.2, and Bmac0113E) on the long arm of chromosome $2 \mathrm{H}$ showed linkage relationships with the genotype data of the two fragments. With the "try" command, the $H \nu C K 2 A$ gene was always located in the centromeric region, between Ebmac0684 on the short arm and $\mathrm{ABG} 356$ on the long arm, and was designated $H v C K 2 a-2 H$ (Fig. 3A).

To determine the chromosome arm, the $H \nu C K 2 A$ probe was hybridized to digested total DNA of $\mathrm{CS}+2 \mathrm{HL}$ and $\mathrm{CS}+2 \mathrm{HS}$. The probe hybridized to two fragments, a $6.6 \mathrm{~kb}$ EcoRI fragment and a $9.5 \mathrm{~kb} K p n \mathrm{I}$ fragment. Both fragments were assigned to the short arm of chromosome $2 \mathrm{H}$ (data not shown). We concluded that $H v C K 2 a-2 H$ is located on the short arm of chromosome $2 \mathrm{H}$ in the following position: X2.1, Pox, MWG949B, Hot1, Ebmac0684, HvCK2a-2H, centromere, ABG356, X2.2, Bmag0113E. Moreover, $H v C K 2 a-2 H$ was found to be linked to Ebmac0684 by 2.4 $\mathrm{cM}$ and to $\mathrm{ABG} 356$ by $7.2 \mathrm{cM}$ (Fig. 3A).

\section{Genetic mapping on chromosome $5 \mathrm{H}$}

Using 16 restriction enzymes, 5 polymorphic fragments were identified between Steptoe and Morex. Steptoe-specific fragments were the $5.5 \mathrm{~kb} \mathrm{BamHI}$ and $7.0 \mathrm{~kb} \mathrm{XbaI}$ fragments. Morex-specific fragments were the $10.0 \mathrm{~kb}$ Apal, $9.4 \mathrm{~kb} \mathrm{BamHI}$, and $9.4 \mathrm{~kb} \mathrm{XbaI}$ fragments. In the doubled haploid lines, all polymorphic fragments co-segregated and contributed to a single locus. Using the "near" command of MAPMAKER with the threshold of the likelihood value at 3.0, we identified 26 markers linked to $H v C K 2 A$ on the long arm of chromosome $5 \mathrm{H}$. With the "try" command, the $H v C K 2 A$ gene on chromosome $5 \mathrm{H}$ (designated $\mathrm{HvCK} 2 \mathrm{a}-5 \mathrm{H}$ ) was always located between WG644 and ABG712, $1.0 \mathrm{cM}$ from each marker (Fig. 3B).

\section{Chromosome assignment of the $H v C K 2 A$ sequence}

To determine which chromosome contains the original $H v C K 2 A$ sequence (Fig. 1), PCR-Southern hybridization was conducted using genomic DNA of 'Chinese Spring' and 'Betzes' and a set of wheat-barley disomic addition lines. With the primer set Hvck2a-F and Hvck2a-R, a single $5.7 \mathrm{~kb}$ fragment was amplified from the genomic DNA of 'Chinese Spring' (Fig. 4A, lane 1) and hybridized with the $H v C K 2 A$ probe (Fig. 4B, lane 1). In 'Betzes', a single $5.0 \mathrm{~kb}$ fragment was amplified (Fig. 4A, lane 2) and hybridized with $H v C K 2 A$ (Fig. 4B, lane 2). Among the set of 'Betzes' chromosome addition lines, a 'Betzes'-specific $5.0 \mathrm{~kb}$ fragment was amplified and hybridized with the $H v C K 2 A$ sequence in the $5 \mathrm{H}$ chromosome addition line (Fig. 4A, lane 6; Fig. 4B, lane 6). We concluded that the present cDNA sequence of $H v C K 2 A$ originated from the genomic region encoding the CK2A gene on chromosome $5 \mathrm{H}$. In comparison with the 1158 bp cDNA sequence between primers Hvck2a-F and Hvck2a-R, the genomic sequence of 
Fig. 1. The nucleotide and deduced amino acid sequences of barley cDNAs encoding (A) casein kinase 2 alpha subunit (CK2A; acc. no. $A B 252049$ ) and (B) casein kinase 2 beta subunit (CK2B; acc. no. AB252050). The stop codon is denoted by an asterisk. Characteristic domains of CK2A and CK2B are underlined: (A) ATP binding site, basic stretch (NLS), catalytic loop, and activation segment; (B) N-terminal extension region, KEN box and D-box (putative degradation motifs), acidic stretch, zinc finger domain (dimer formation), and positive regulatory region (binding to catalytic subunit).

(A)

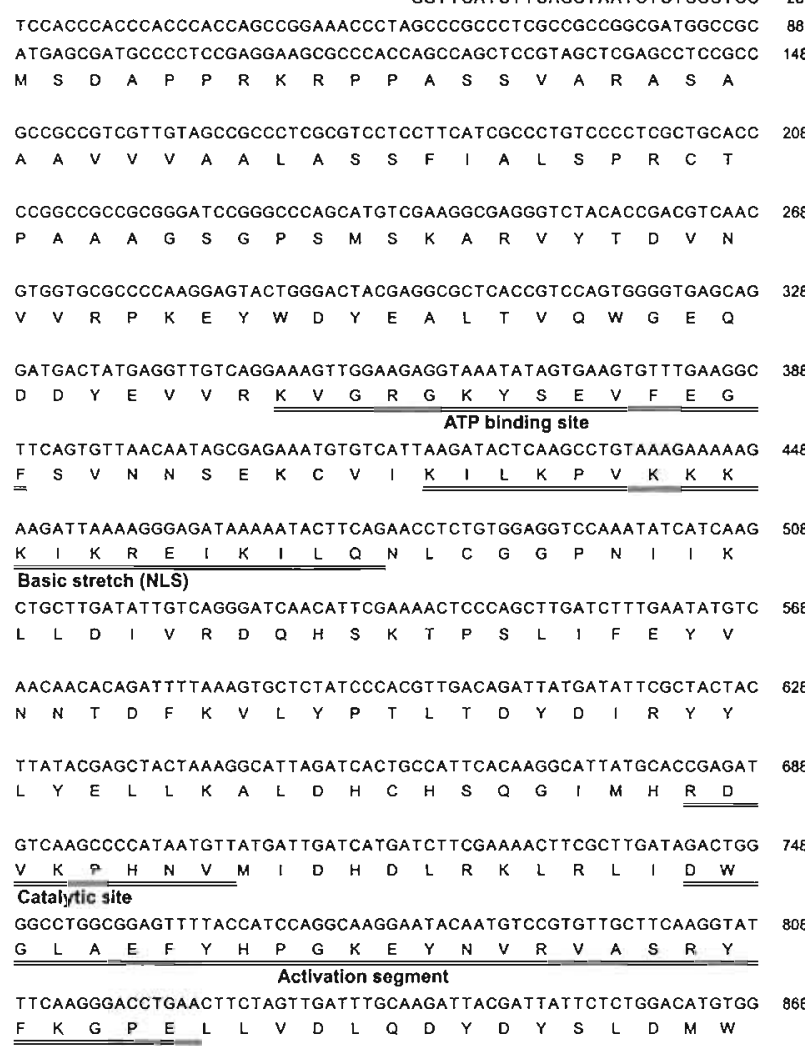
AGCCTTGGGTGCATGTTTGCTGGGATGATCTTCCGCAAGGAGCCATTCTTCTATGGCCAT 928 $\begin{array}{llllllllllllllllllllll}S & L & G & C & M & F & A & G & M & I & F & R & K & E & P & F & F & Y & G & H\end{array}$

GATAACCATGACCAACTTGTGAAAATTGCGAGGTACTTGGAACAGACAGCCTGAATGCT 988 $\begin{array}{llllllllllllllllllll}D & N & H & D & Q & L & V & K & \text { I } & A & K & V & L & G & T & D & S & L & N & A\end{array}$

TACT IAAAGAAGIACCACCITGAGCTTGACCCTCAGCTTGAACATCTTGTTGGAAGGCAC 1048

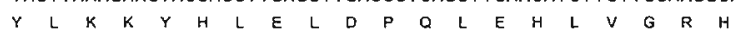

AGTAGAAAACCCTGGTCAAAGTTCATTAATGCTGATAACCAGGATCTAGTATCTCGCGAG 1108 $\begin{array}{llllllllllllllllllll}S & R & K & P & W & S & K & F & I & N & A & D & N & Q & H & L & V & S & P & E\end{array}$

GCCATAGATTTTCTCGATAAGCTTCTTCGCTATGATCACCAAGATAGGCTCACTGCTCGT 1168 A I

GAAGCTATGGCGCATCCATACTTCCTTCAAGTGAGAGCAGCGGAGAACAGCAGGGCACGA 1228 E A

CCGCAATGACATTGAGTGTGCACCGTGCAAAGTGGAGCAGTTGCTAATTGTTACTGATCA 1288 $P Q$.

TCACATGATGGAACTGTCACGATGGCAACTTGATCCAACTATCCGTCCTATGCACTGAGA 1348 TGGCGGTTJGAGTCGCTATGCTGTAAGAGGTTGTAACATTGTACTATTTGTAAACTTCAG 1408 AGCACTCTGTITACYCCAGTGATAGTGGTCGATGAATGTGGTGGCATGCATGCCACCATT 1468 TGTGTAACAGGGIAAGTAAAT TGCCIGCATTGGGCAGTCCTAAGACCCAACAGTTTACTT 1528 GTGTTGTTAAGAGTTACAATAGTCAAATGTATGGTCATTTTTTATTGCGATTATTTTGTA 1588 CTGTTTTTGAAACAAAAAAAAAA

'Betzes' was $5.0 \mathrm{~kb}$. These results demonstrated that the total intron is almost four fifths of the genomic coding region of $\mathrm{HvCK} 2 \mathrm{a}-5 \mathrm{H}$.
Fig. 1 (concluded).

(B)

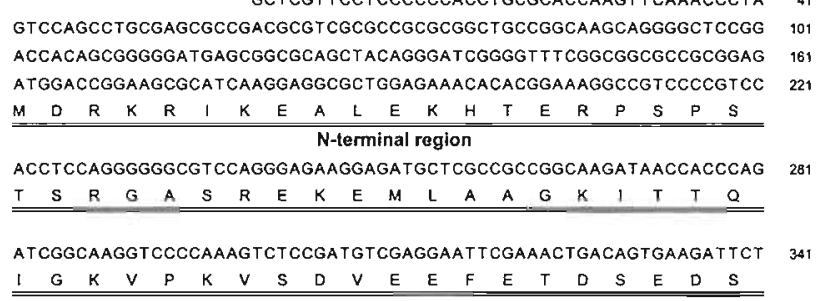
GATGITAGCGGTTCTGAAGGAGAGACACATCTTGGATTTCATGGTTCTGTAGCTTGCGA 401 $\begin{array}{llllllllllllllllllll}D & V & S & G & S & E & G & E & D & T & S & W & I & S & W & F & C & S & L & R\end{array}$

GGCAACGAATYCTTCTGTGAGATTGATGATGATTATATACAGGATGATTTCAATCTCTGT 461

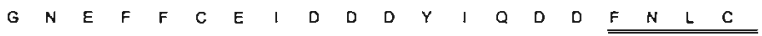

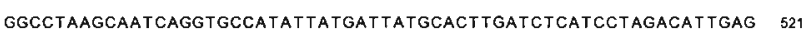
$\begin{array}{lllllllllllllllllllllllll}G & L & S & N & Q & V & P & Y & Y & D & Y & A & L & D & L & I & L & D & I\end{array}$ KEN bOX D-box

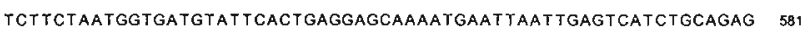
$S \begin{array}{llllllllllllllllllll}S & N & G & D & V & F & T & E & E & Q & N & E & L & I & E & S & S & A & E\end{array}$ ATGGTGTATGGTTTAATCCATGCACGgTACATCTTAAGTAGGAAGGGTCTAGGTGCAATG GA1

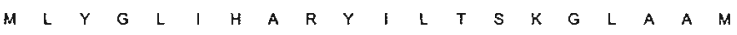

ITAGAAAAGTTCAAGAATTATGATTYTGGCAGATGCCCTCGAGTATACTGCTGTGGCCAG 701

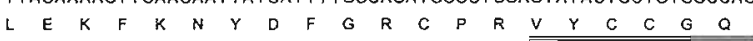

CCCTGTCTTCCAGCAGGGCAATCAGACATTCCTAGGTCAAGCACAGTGAAGGTGTTTGT $76 \%$ \begin{tabular}{llllllllllllllllllll}
$\mathrm{P}$ & $\mathrm{C}$ & $\mathrm{L}$ & $\mathrm{P}$ & $\mathrm{A}$ & $\mathrm{G}$ & $\mathrm{O}$ & $\mathrm{S}$ & $\mathrm{D}$ & $\mathrm{I}$ & $\mathrm{P}$ & $\mathrm{R}$ & $\mathrm{S}$ & $\mathrm{S}$ & $\mathrm{T}$ & $\mathrm{V}$ & $\mathrm{K}$ & $V$ & $\mathrm{~F}$ & $\mathrm{C}$ \\
\hline \hline
\end{tabular} Zinc finger domain

CCAAAATGTGAAGACTTACACTATCCAAGGTCCAAGTACCAAGGCAACATTGATGGAGCA 821

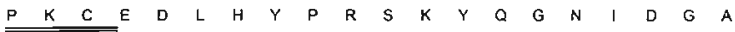

TACTTTGgTACGACGTTCCCTCATCTCTTCTTGATGACATATCCACACCTGAaGCCACAG 881

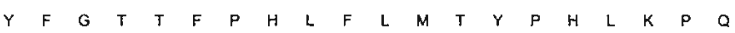

AAGCCATCACAGCAATACGTTCCAAGGGTTTTTGGCTTCAAACTTCACAAGCAGTCGTGA 941 \begin{tabular}{llllllllllllllllllll}
$K$ & $P$ & $S$ & $Q$ & $Q$ & $Y$ & $V$ & $P$ & $R$ & $V$ & $F$ & $G$ & $F$ & $K$ & $L$ & $H$ & $K$ & $Q$ & $S$ \\
\hline
\end{tabular} Positive regulatory region

CAAACTTTTACCAGGGgGGCAATTTGTTTTTACCTAGTGTTAGAGATGGAACACCATGG 100 CCTCAAAATGTTGTGGCCTCTTGATTGGAGTACTGGCGAGCTTGAATCTTGCTGYCAACT 1061 GCTGAGCAACTGTATCTGTTTTGTTGTATGACTGCTGTGTAATCTAGGTTTCTTCACTTG 1121 ATCAAGCTATGCACATT TGCATGTTAAAAAAAAAAAAAAAAAA

1164

\section{Molecular mapping of $\mathrm{HvCK2B}$}

\section{Chromosome assignments}

One to three restriction fragments hybridizing with $H v C K 2 B$ were detected in 'Betzes' DNA digested by 6 restriction enzymes (Fig. 2). The $15.0 \mathrm{~kb} A p a \mathrm{I}, 6.6 \mathrm{~kb} \mathrm{BamHI}$, $9.4 \mathrm{~kb}$ and $3.0 \mathrm{~kb} \mathrm{BglII}, 5.0 \mathrm{~kb}$ and $2.5 \mathrm{~kb} \mathrm{Dral,}$ and $2.1 \mathrm{~kb}$ and $10 \mathrm{~kb} X b a \mathrm{I}$ fragments were specific to 'Betzes'. No fragment was detected in 'Betzes' by $K p n I$ digestion. From Southern blotting of each chromosome addition line, no 'Betzes' fragment was assigned to chromosome $2 \mathrm{H}, 3 \mathrm{H}$, $4 \mathrm{H}, 5 \mathrm{H}, 6 \mathrm{H}$, or $7 \mathrm{H}$. The data demonstrated the possibility that $H \nu C K 2 B$ is located on chromosome $1 \mathrm{H}$.

\section{Genetic mapping}

RFLP assays were conducted with 11 restriction enzymes to detect polymorphic fragments between Steptoe and Morex. Of all the fragments detected in Steptoe and Morex in the present study, only one was polymorphic between the parental lines. The $15 \mathrm{~kb}$ EcoRI fragment was present in Morex but not in Steptoe. Genotype data of this fragment were added to the previously reported mapping data. Using the "near" command of MAPMAKER with the threshold of the likelihood value at 3.0 , we identified 25 markers linked to $H v C K 2 B$ on the long arm of chromosome $1 \mathrm{H}$. Using the 
Fig. 2. Chromosome assignment of the casein kinase 2 alpha subunit gene (A) and beta subunit gene (B) in Hordeum vulgare 'Betzes'. Genomic DNA from Triticum aestivum 'Chinese Spring' (lane 1), 'Betzes' (lane 2), and wheat-barley disomic chromosome addition lines $\mathrm{CS}+2 \mathrm{H}$ (lane 3), CS + 3H (lane 4), CS + 4H (lane 5), CS + 5H (lane 6), CS + 6H (lane 7), and CS + 7H (lane 8). The molecular weight (kilobases) is presented on the left side of each panel.

A

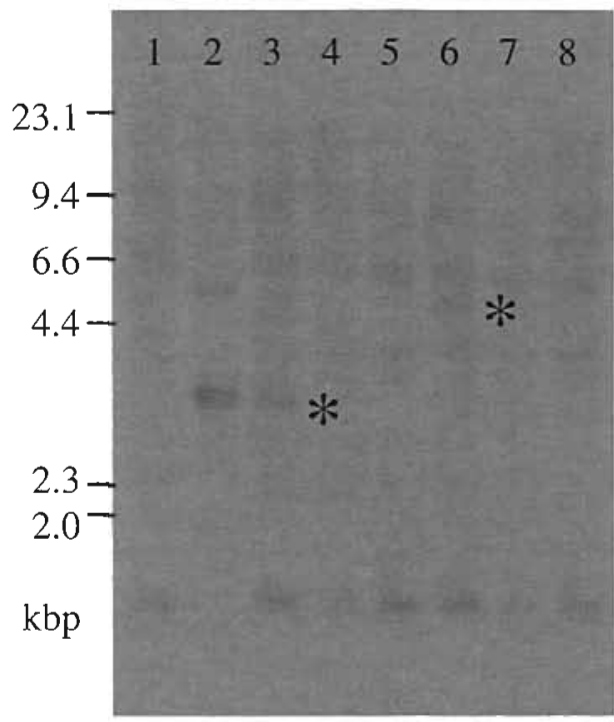

B

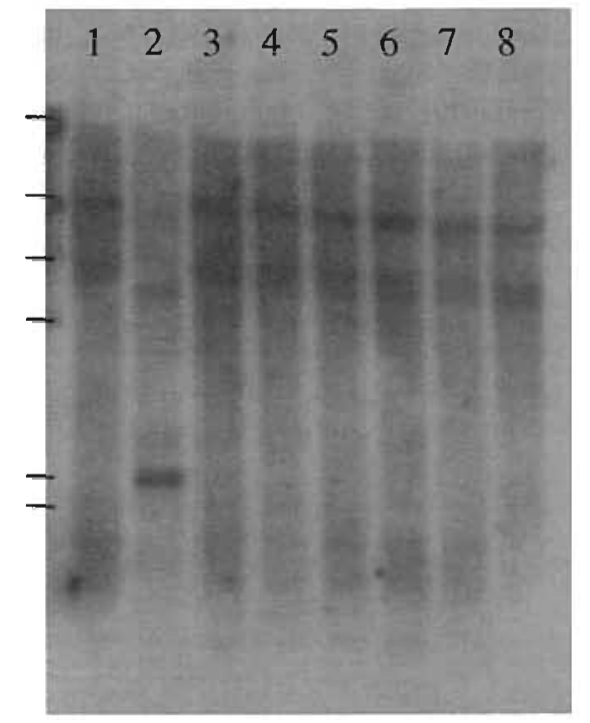

Fig. 3. Genetic linkage map of duplicate casein kinase 2 alpha subunit (CK2A) genes on chromosomes $2 \mathrm{H}$ and $5 \mathrm{H}$ in barley $(H$. vulgare). In the Oregon Wolf Barley mapping population, the CK2A gene was located between Ebmac0684 on the short arm and ABG356 on the long arm of barley chromosome $2 \mathrm{H}$, and designated $H v C K 2 a-2 H$ (A). In wheat-barley $2 \mathrm{H}$ chromosome arm disomic addition lines, the centromere was assigned between $H v C K 2 a-2 H$ and ABG356 in the present study. In doubled haploid lines of a cross between Steptoe and Morex, the CK2A gene was located between WG644 and ABG712 on the long arm of barley chromosome $5 \mathrm{H}$ and designated $H v C K 2 a-5 H(B)$. Black arrows indicate the centromere positions.

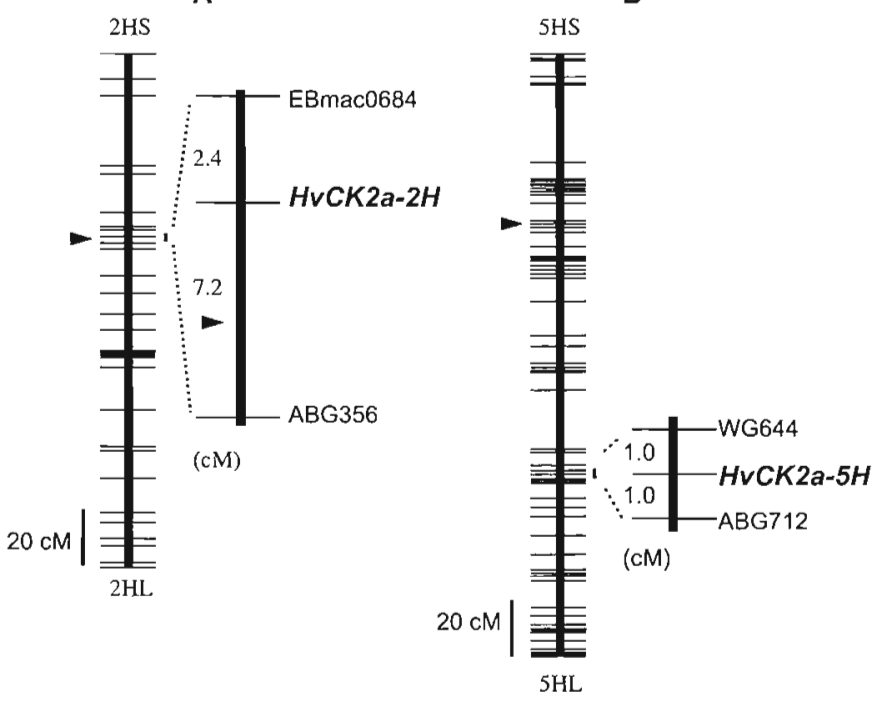

"try" command, we found that $H v C K 2 B$ co-segregated with CDO105B and MWG800, was located between ABR337 and $\mathrm{ABG} 494$, and was linked to $\mathrm{ABR} 337$ and $\mathrm{ABG} 494$ by $4.0 \mathrm{cM}$ and $6.0 \mathrm{cM}$, respectively (Fig. 5).

\section{Discussion}

Three CK2 subunit genes are coincident with heading time QTLs

CK2 is essential for photoperiodic regulation of flowering time, as shown by studies of CKB3 and CKB4, which are casein kinase 2 regulatory subunits, overexpressed in transgenic Arabidopsis plants (Sugano et al. 1999; Portolés and Más 2007). In rice, a CK2 alpha subunit encoded by Hd6 is involved in the photoperiodic flowering response (Takahashi et al. 2001). These findings demonstrate the importance of CK2 function in the regulation of flowering in both longday and short-day plants. The genetic control of variation in flowering time has also been extensively studied in the tribe Triticeae. The objective of the present study was to map the CK2 subunit genes and compare the positions of these genes with the reported QTL positions (GrainGenes; http://wheat. pw.usda.gov/cgi-bin/graingenes/browse.cgi). Conserved genomic locations for genes involved in vernalization and photoperiodic induction have been identified among species by comparative genetic studies (Dubcovsky et al. 1998). Comparative maps between barley and wheat have demonstrated that $H v C K 2 a-5 H$ should be orthologous to the wheat locus $t c k 2 a$, which has been found to be closely linked to $\mathrm{Vrn}-\mathrm{Al}$ on the long arm of wheat chromosome $5 \mathrm{~A}$ (Kato et al. 2002). In barley, the marked variation of days to heading is dependent on both vernalization and day length: in doubled haploid lines derived from the cultivars Dicktoo and Morex, a heading QTL responsive to vernalization was found on chromosome 7, at a syntenic region with wheat $\mathrm{Vrn}-\mathrm{Al}$ (Pan et al. 1994). The vernalization effect could be due to allelic variation at the $\mathrm{Vrn}-\mathrm{Hl}(\mathrm{Sh} 2)$ locus (Pan et al. 1994). Our data demonstrate the possibility that an alternative photoperiod response effect corresponds to the $\mathrm{HvCK} 2 \mathrm{a}-5 \mathrm{H}$ gene. The Dicktoo allele is associated with an increase in the days to heading under long-day conditions when com- 
Fig. 4. PCR-Southern blotting for chromosome assignment of the $H v C K 2 A$ sequence. (A) Electrophoresis of PCR products using the primer set Hvck2a-F (5'-ATGGCCGCATGAGCGATGC-3') and Hvck2a-R (5'-TCATTGCGGTCGTGCCCTG-3'). Lane M, molecular size markers. PCR template was genomic DNA of Triticum aestivum 'Chinese Spring' (lane 1) and Hordeum vulgare 'Betzes' (lane 2), wheat-barley disomic chromosome addition lines $\mathrm{CS}+2 \mathrm{H}$ (lane 3), $\mathrm{CS}+3 \mathrm{H}$ (lane 4), $\mathrm{CS}+4 \mathrm{H}$ (lane 5), $\mathrm{CS}+5 \mathrm{H}$ (lane 6), $\mathrm{CS}+6 \mathrm{H}($ lane 7$), \mathrm{CS}+7 \mathrm{H}$ (lane 8 ), and distilled water as a negative control (lane 9). (B) PCR products hybridized with the $H v C K 2 A$ sequence.

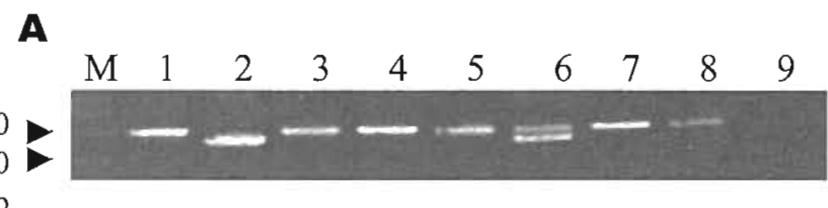

$\mathbf{B}$

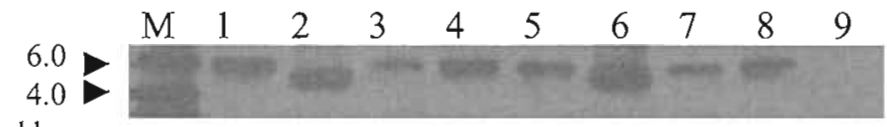

$\mathrm{kbp}$

pared with the Morex allele (Pan et al. 1994). Similarly, the functional $H d 6$ allele of the indica rice cultivar Kasalath increased the days to heading under long-day conditions when compared with the nonfunctional allele of the japonica rice cultivar Nipponbare (Yamamoto et al. 2000; Takahashi et al. 2001). In addition, Szúcs et al. (2006) reported that the phytochrome gene $H v P h y C$ was also located in this genomic region, showing the possibility that allelic variation of $H v P h y C$ contributes to the variation in photoperiod response. The parental lines Dicktoo and Morex and the doubled haploid lines are suitable genetic materials to elucidate the functions of $H v C K 2 a-5 H$ and $H v P h y C$ in photoperiod responses in barley.

Although there was no $H \nu C K 2 a-2 H$ transcript in the present cDNA library from 5 -day-old $H$. vulgare 'Minorimugi', $H v C K 2 a-2 H$ was coincident with several heading time QTLs including eps2, QHd.HaMo-2H, QHD.dah-2H.1, QHd.lgDa-2H, QHD.umn-2H.1, QHea.pil-2H.2, and QHea.pil-2H.3 in the centromeric region of chromosome 2H (Backes et al. 1995; Laurie et al. 1995; Marquez-Cedillo et al. 2001; Dahleen et al. 2003; Mesfin et al. 2003; Pillen et al. 2003). All QTLs were identified in field trials. To clarify whether each QTL controls the photoperiod response, the effect on heading date under variable conditions combined with photoperiod and vernalization needs to be elucidated. $H v C K 2 b$ was located in the proximal portion of 1HL coincident with several heading date QTLs including QHd.DiMo-lH.l (Pan et al. 1994), QHdHaMo1H.1 (Marquez-Cedillo et al. 2001), and QHD.umn- $1 H$ (Mesfin et al. 2003). Pan et al. (1994) collected data on heading dates under variable day length with and without vernalization. QHd.DiMo- 1 H.I had a significant effect under short-day conditions but not under long-day conditions, suggesting that $Q H d . D i M o-1 H .1$ controls photoperiod response. To investigate whether $H v C K 2 b$ is associated with the photoperiod response at QHd.DiMo-1H.1, Dicktoo
Fig. 5. Genetic linkage map of the casein kinase 2 beta subunit gene $(H \nu C K 2 B)$ on chromosome $1 \mathrm{H}$ of barley (H. vulgare). Using doubled haploid lines of a cross between Steptoe and Morex, $H v C K 2 B$ co-segregated with CDO105B and MWG800 and was located between ABR337 and ABG494 on the long arm of barley chromosome $1 \mathrm{H}$; it was designated $H v C K 2 b$. The black arrowhead indicates the centromere position.

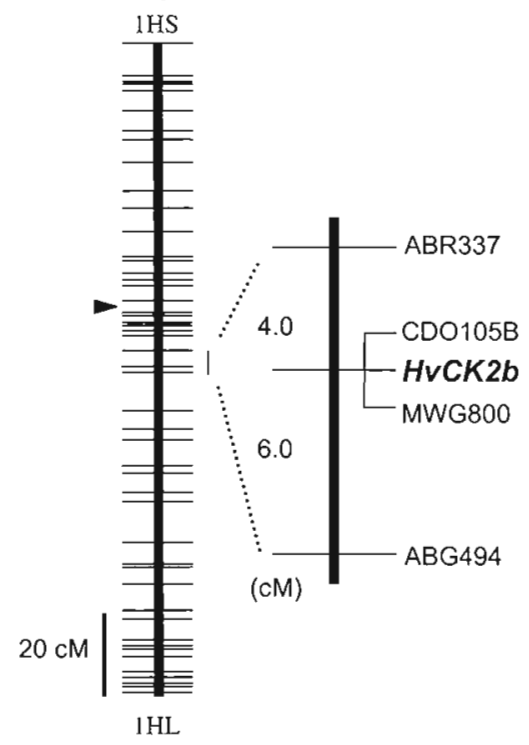

and Morex and their doubled haploid lines are again suitable genetic materials.

\section{Genomic organization of CK2 alpha and beta subunit genes}

In animal genomes, the CK2 subunits are encoded by a maximum of 4 genes, e.g., 1 gene for the alpha subunit and 1 for the beta subunit in Caenorhabditis elegans, 2 genes for the alpha subunits and 1 gene for the beta subunit in human, and 2 genes for the alpha subunits and 2 genes for the beta subunits in yeast. In plant genomes, multiple genes for CK2 subunits have been reported. The Arabidopsis genome has 8 genes coding for CK2 subunits, 4 alpha and 4 beta subunit genes (Salinas et al. 2006), and the rice genome has at least 6 genes coding for putative CK2 subunits, 4 alpha subunit genes and 2 beta subunit genes (Rice Annotation Project Database; http://rapdb.lab.nig.ac.jp/index.html). In maize, 6 genes coding for $\mathrm{CK} 2$ subunits have been identified and characterized to date (Peracchia et al. 1999; Riera et al. 2001, 2003). As reported here, barley has the smallest number of genes for CK2 subunits in plants analyzed to date. Salinas et al. (2006) showed that multiple loci in Arabidopsis are located in the self-duplicated region, suggesting that each duplicated pair of genes could be functionally redundant. No obvious phenotype was identified in single T-DNA insertional mutant plants for all putatively duplicated CK2 subunit genes in Arabidopsis (Salinas et al. 2006). Barley is a good model plant for the functional analysis and regulation of CK2 activity in plants. The present study will facilitate CK2 activity regulation and functional analysis in barley.

\section{Acknowledgements}

The Steptoe/Morex doubled haploid lines were developed 
by the North Barley Genome Mapping Project, and seed for the present study was kindly provided by Dr. K. Sato, Okayama University, Japan. Oregon Wolf Barley doubled haploid lines were developed and kindly provided by Oregon State University, USA. Wheat-barley disomic chromosome (arm) addition lines were kindly provided by Dr. Sasakuma, Yokohama City University, Japan; Dr. Furuta, Gifu University, Japan; and Dr. Koba, Chiba University, Japan. The authors acknowledge Nobuko Ito-Akasaka and Nanako Sumitani for their technical support.

\section{References}

Akten, B., Jauch, E., Genova, G.K., Kim, E.Y., Edery, I., Raabe, T., and Jackson, E.R. 2003. A role for CK2 in the Drosophila circadian oscillator. Nat. Neurosci. 6: 251-257. doi:10.1038/ nn 1007. PMID: 12563262.

Backes, G., Graner, A., Foroughi-Wehr, B., Fischbeck, G., Wenzel, G., and Jahoor, A. 1995. Localization of quantitative trait loci (QTL) for agronomic important characters by the use of a RFLP map in barley (Hordeum vulgare L.). Theor. Appl. Genet. 90: 294-302. doi:10.1007/BF00222217.

Barz, T., Ackermann, K., Dubois, G., Eils, R., and Pyerin, W. 2003. Genome-wide expression screens indicate a global role for protein kinase $\mathrm{CK} 2$ in chromatin remodeling. J. Cell Sci. 116: 1563-1577. doi: 10.1242/jcs.00352. PMID: 12640040.

Boldyreff, B., and Issinger, O.-G. 1997. A Raf kinase is a new interacting partner of protein kinase CK2 $\alpha$ subunit. FEBS Lett. 403: 197-199. doi:10.1016/S0014-5793(97)00010-0. PMLD: 9042965 .

Chen, M., Li, D., Krebs, E.G., and Cooper, J.A. 1997. The casein kinase II beta subunit binds to Mos and inhibits Mos activity. Mol. Cell. Biol. 17: 1904-1912. PMID:9121438.

Costa, J.M., Corey, A., Hayes, P.M., Jobet, C., Kleinhofs, A., Kopisch-Obusch, A., et al. 2001. Molecular mapping of the Oregon Wolfe Barleys: a phenotypically polymorphic doubled-haploid population. Theor. Appl. Genet. 103: 415-424. doi:10.1007/ s001220100622.

Dahleen, L.S., Agrama, H.A., Horsley, R.D., Steffenson, B.J., Schwarz, P.B., Mesfin, A., and Franckowiak, J.D. 2003. Identification of QTLs associated with Fusarium head blight resistance in Zhedar 2 barley. Theor. Appl. Genet. 108: 95-104. doi:10. 1007/s00122-003-1409-7. PMID: 14556050.

Daniel, X., Sugano, S., and Tobin, E.M. 2004. CK2 phosphorylation of CCAl is necessary for its circadian oscillator function in Arabidopsis. Proc. Natl. Acad. Sci. U.S.A. 101: 3292-3297. doi: 10.1073/pnas.0400163101. PMID: 14978263.

Dobrowolska, G., Meggio, F., Szczegielniak, J., Muszynska, G., and Pinna, L.A. 1992. Purification and characterization of maize seedling casein kinase IIB, a monomeric enzyme immunologically related to the alpha subunit of animal casein kinase-2. Eur. J. Biochem. 204: 299-303. doi:10.1111/j.1432-1033.1992. tb16637.x. PMID:1740141.

Dubcovsky, J., Lijavetzky, D., Appendino, L., and Tranquilli, G. 1998. Comparative RFLP mapping of Triticum monococcum genes controlling vernalization requirement. Theor. Appl. Genet. 97: 968-975. doi:10.1007/s001220050978.

Espunya, M.C., and Martinez, M.C. 1997. Identification of two different molecular forms of Arabidopsis thaliana casein kinase II. Plant Sci. 124: 131-142. doi:10.1016/S0168-9452(96)04599-2.

Espunya, M.C., Combettes, B., Dot, J., Chaubet-Gigot, N., and Martinez, M.C. 1999. Cell-cycle modulation of CK2 activity in tobacco BY-2 cells. Plant J. 19: 655-666. doi:10.1046/ j.1365-313x.1999.00563.x. PMID:10571851.
Hanna, D.E., Rethinaswamy, A., and Glover, C.V. 1995. Casein kinase $\Pi$ is required for cell cycle progression during $G l$ and G2/M in Saccharomyces cerevisiae. J. Biol. Chem. 270: $25905-$ 25914. doi:10. 1074/jbc.270.43.25905. PMID:7592778.

Hériché, J.K., Lebrin, F., Rabilloud, T., Leory, D., Chambaz, E.M., and Goldberg, Y. 1997. Regulation of protein phosphatase 2A by direct interaction with casein kinase $2 \alpha$. Science (Washington, D.C.), 276: 952-955. doi:10.1126/science.276.5314. 952. PMID:9139659.

Islam, A.K.M.R., Shepherd, K.W., and Sparrow, D.H.B. 1981. Isolation and characterization of euplasmic wheat-barley chromosome addition lines. Heredity, 46: 161-174.

Kato, K., Kidou, S., Miura, H., and Sawada, S. 2002. Molecular cloning of the wheat $C K 2 \alpha$ gene and detection of its linkage with Vrn-AI on chromosome 5A. Theor. Appl. Genet. 104: 1071-1077. doi:10.1007/s00122-001-0805-0. PMID:12582614.

Kleinhofs, A., Kilian, A., Saghai Maroof, M., Biyashev, R.M., Hayes, P.M., Chen, F., et al. 1993. A molecular, isozyme, and morphological map of the barley (Hordeum vulgare) genome. Theor. Appl. Genet. 86: 705-712. doi:10.1007/BF00222660.

Klimczak, L.J., and Cashmore, A.R. 1994. Microheterogeneous cytosolic high-mobility group proteins from broccoli co-purify with and are phosphorylated by casein kinase II. Plant Physiol. 105: 911-919. PMID: 12232253.

Kosambi, D.D. 1944. The estimation of map distances from recombination values. Ann. Eugen. 12: 172-175.

Lander, E.S., Green, P., Abranhamson, J., Barlow, A., Daly, M.J., Lincoln, S.E., and Newburg, L. 1987. MAPMAKER: an interactive computer package for constructing primary genetic linkage maps of experimental and natural populations. Genomics, 1: 174-181. doi:10.1016/0888-7543(87)90010-3. PMID:3692487.

Laurie, D.A., Pratchett, N., Bezant, J.H., and Snape, J.W. 1995. RFLP mapping of five major genes and eight quantitative trait loci controlling flowering time in a winter $\times$ spring barley (Hordeum vulgare L.) cross. Genome, 38: 575-585. doi:10.1139/ G95-074

Lin, J.M., Kilman, V.L., Keegan, K., Paddock, B., Emery-Le, M., Rosbash, M., and Allada, R. 2002. A role for casein kinase 2 alpha in the Drosophila circadian clock. Nature (London), 420: 816-820. doi:10.1038/nature01235. PMID: 12447397.

Lüscher, B., Kuenzel, E.A., Krebs, E.G., and Eisenman, R.N. 1989. Myc oncoproteins are phosphorylated by casein kinase II. EMBO J. 8: 1111-1119. PMID:2663470.

Marquez-Cedillo, L.A., Hayes, P.M., Kleinhofs, A., Legge, W.G., Rossnagel, B.G., Sato, K., et al. 2001. QTL analysis of agronomic traits in barley based on the doubled haploid progeny of two elite North American varieties representing different germplasm groups. Theor. Appl. Genet. 103: 625-637. doi:10.1007/ PL00002919.

Meggio, F., and Pinna, L.A. 2003. One-thousand-and-one substrates of protein kinase CK2? FASEB J. 17: 349-368. doi: 10. 1096/fj.02-0473rev. PMID: 12631575.

Mesfin, A., Smith, K.P., Dill-Macky, R., Evans, C.K., Waugh, R., Gustus, C.D., and Muehlbauer, G.J. 2003. Quantitative trait loci for Fusarium head blight resistance in barley detected in a tworowed by six-rowed population. Crop Sci. 43: 307-318.

Murray, M.G., and Thompson, W.F. 1980. Rapid isolation of high molecular weight plant DNA. Nucleic Acids Res. 8: 4321. doi:10.1093/nar/8.19.4321. PMID:7433111.

Ospina, B., Nunez, A., and Fernandez-Renart, M. 1992. Purification of a soluble casein kinase II from Dictyostelium discoideum lacking the beta subunit: regulation during proliferation and differentiation. Mol. Cell. Biochem. 118: 49-60. doi:10.1007/ BF00249694. PMID:1488055. 
Pan, A., Hayes, P.M., Chen, F., Chen, T.H.H., Blake, T., Wright, S., et al. 1994. Genetic analysis of the components of winterhardiness in barley (Hordeum vulgare L.). Theor. Appl. Genet. 89: 900-910. doi:10.1007/BF002245l6.

Peracchia, G., Jensen, A.B., Culiàñez-Macià, F.A., Grosset, J., Goday, A., Issinger, O.G., and Pagés, M. 1999. Characterization, subcellular localization and nuclear targeting of casein kinase 2 from Zea mays. Plant Mol. Biol. 40: 199-211. doi:10.1023/ A: 1006196530079 . PMID: 10412900.

Pillen, K., Zacharias, A., and Léon, J. 2003. Advanced backcross QTL analysis in barley (Hordeum vulgare L.). Theor. Appl. Genet. 107: 340-352. doi:10.1007/s00122-003-1253-9. PMID: 12677407.

Portolés, S., and Más, P. 2007. Altered oscillator function affects clock resonance and is responsible for the reduced day-length sensitivity of CKB4 overexpressing plants. Plant J. 51: 966977. doi:10.1111/j.1365-313X.2007.03186.x. PMID:17662034.

Riera, M., Peracchia, G., de Nadal, E., Arino, J., and Pages, M. 2001. Maize protein kinase CK2: regulation and functionality of three $\beta$ regulatory subunits. Plant J. 25: $365-374$. doi: 10.1046/j. 1365-313x.2001.00973.x. PMID:1 1260493.

Riera, M., Pages, M., Issinger, O.-G., and Guerra, B. 2003. Purification and characterization of recombinant protein kinase $\mathrm{CK} 2$ from Zea mays expressed in Escherichia coli. Protein Expr. Purif. 29: 24-32. doi:10.1016/S1046-5928(03)00005-6. PMID: 12729722.

Salinas, P., Fuentes, D., Vidal, E., Jordana, X., Echeverria, M., and Holuigue, L. 2006. An extensive survey of CK2 $\alpha$ and $\beta$ subunits in Arabidopsis: multiple isoforms exhibit differential subcellular localization. Plant Cell Physiol. 47: 1295-1308. doi:10. 1093/pcp/pcj100. PMID: 16926165.

Seldin, D.C., and Leder, P. 1995. Casein kinase II alpha transgeneinduced murine lymphoma: relation to theileriosis in cattle. Science (Washington, D.C.), 267: 894-897. doi:10.1126/science. 7846532. PMID: 7846532.

Shinozuka, H., Hisano, H., Ponting, R.C., Cogan, N.O.I., Jones, E.S., Forster, J.W., and Yamada, T. 2005. Molecular cloning and genetic mapping of perennial ryegrass casein protein kinase
$2 \alpha$-subunit genes. Theor. Appl. Genet. 112: 167-177. doi: 10 . 1007/s00122-005-01 19-8. PMID:16240106.

Sugano, S., Andronis, C., Green, R.M., Wang, Z.Y., and Tobin, E.M. 1998. Protein kinase CK2 interacts with and phosphorylates the Arabidopsis circadian clock-associated 1 protein. Proc. Natl. Acad. Sci. U.S.A. 95: 11020-11025. doi:10.1073/pnas.95. 18.11020. PMID:9724822.

Sugano, S., Andronis, C., Ong, M.S., Green, R.M., and Tobin, E.M. 1999. The protein kinase CK2 is involved in regulation of circadian rhythms in Arabidopsis. Proc. Natl. Acad. Sci. U.S.A. 96: 12362-12366. doi:10.1073/pnas.96.22.12362. PMID:10535927.

Szúcs, P., Karsai, I., von Zitzewitz, J., Mészáros, K., Cooper, L.L.D., Gu, Y.Q., et al. 2006. Positional relationships between photoperiod response QTL and photoreceptor and vernalization genes in barley. Theor. Appl. Genet. 112: 1277-1285. doi:10. 1007/s00122-006-0229-y. PMID:16489429.

Takahashi, Y., Shomura, A., Sasaki, T., and Yano, M. 2001. Hd6, a rice quantitative trait locus involved in photoperiod sensitivity, encodes the alpha subunit of protein kinase CK2. Proc. Natl. Acad. Sci. U.S.A. 98: 7922-7927. doi:10.1073/pnas.111136798. PMID:11416158.

Turner, A., Beales, J., Faure, S., Dunford, R.P., and Laurie, D.A. 2005. The pseudo-response regulator $\mathrm{Ppd-HI}$ provides adaptation to photoperiod in barley. Science (Washington, D.C.), 310: 1031-1034. doi:10.1126/science.1117619. PMID: 16284181.

Willert, K., Brink, M., Wodarz, A., Varmus, H., and Nusse, R. 1997. Casein kinase 2 associates with and phosphorylates dishevelled. EMBO J. 16: 3089-3096. doi:10.1093/emboj/16.11. 3089. PMW: 9214626.

Yamamoto, T., Lin, H., Sasaki, T., and Yano, M. 2000. Identification of heading date quantitative trait locus $H d 6$ and characterization of its epistatic interactions with $H d 2$ in rice using advanced backcross progeny. Genetics, 154: 885-891. PMID: 10655238.

Yang, Y., Cheng, P., and Liu, Y. 2002. Regulation of the Neurospora circadian clock of casein kinase II. Genes Dev. 16: 994 1006. doi:10. I I01/gad.965102. PMID:11959847. 